\title{
Eukarya 18S rRNA gene diversity in the sea surface microlayer: implications for the structure of the neustonic microbial loop
}

\author{
Michael Cunliffe and J Colin Murrell \\ Department of Biological Sciences, University of Warwick, Coventry, UK
}

\begin{abstract}
We have previously shown that there is a consistent and reproducible bacterioneuston community in the surface microlayer during a fjord mesocosm experiment. One possible cause of the surface microlayer-specific bacterial community is a surface microlayer-specific protist community selectively grazing on the bacterioneuston. We determined protist community structures using Eukarya 18S rRNA gene denaturing gradient gel electrophoresis (DGGE) and subsequent DGGE band sequencing using DNA samples that were collected from the surface microlayer and subsurface water of the mesocosms. As with bacterial communities, protist community structure was consistently different in the surface microlayer when compared with subsurface water. In particular, the protist community in the surface microlayer was dominated by Cercozoa, which were not detected in the subsurface water, and Ciliophora.

The ISME Journal (2010) 4, 455-458; doi:10.1038/ismej.2009.133; published online 10 December 2009
\end{abstract}

Subject Category: microbial population and community ecology

Keywords: sea surface microlayer; microbial loop; Eukarya; fjord; mesocosm; phytoplankton bloom

The sea-surface microlayer is the thin biogenic film at the air-sea interface (Cunliffe and Murrell, 2009). The bacterial community present in the surface microlayer is known as the bacterioneuston and has a different community structure compared with that of subsurface water below (Cunliffe et al., 2008, 2009a, Franklin et al., 2005). Monitoring of the bacterioneuston community structure during a fjord mesocosm experiment, using Bacteria 16S rRNA gene terminal restriction fragment length polymorphism and denaturing gradient gel electrophoresis (DGGE), showed distinct and consistent differences between the bacterioneuston and the bacterioplankton communities (Cunliffe et al., 2009c).

Understanding the mechanisms that regulate microbial communities is a central tenet of microbial ecology. It is now established that protist grazing can have community-level effects and can affect bacterial diversity (Pernthaler, 2005). Both laboratory experiments and field-based studies have shown that the selective grazing of protists upon bacterioplankton communities is important (Pernthaler, 2005).

It is therefore possible that protist grazing in the surface microlayer could be a contributing factor of the surface microlayer-specific bacterioneuston

Correspondence: JC Murrell, Department of Biological Sciences, University of Warwick, Gibbet Hill Road, Coventry, CV4 7AL, UK. E-mail: J.C.Murrell@warwick.ac.uk

Received 21 September 2009; revised 2 November 2009; accepted 5 November 2009; published online 10 December 2009 community structure that we had previously reported (Cunliffe et al., 2009c). To test this hypothesis we must first establish the community structure of protists in the surface microlayer and determine to what extent protist community structure in the surface microlayer is different to that in subsurface water.

Denaturing gradient gel electrophoresis was used to analyse Eukarya 18S rRNA gene amplicons from DNA samples that have been used previously to retrieve Bacteria 16S rRNA gene amplicons (Cunliffe et al., 2009c). The fjord mesocosm experiment monitored bacterioplankton and bacterioneuston community dynamics during an artificially induced phytoplankton bloom in six 24741 mesocosms $(3 \times$ control and $3 \times$ nutrient amended). The phytoplankton bloom was induced by the addition of $16 \mu \mathrm{M} \mathrm{NaNO}$ and $1 \mu \mathrm{M} \mathrm{KH} \mathrm{KO}_{2} \mathrm{PO}_{4}$ and monitored for 11 days. Community samples were collected from the surface microlayer using a metal mesh screen (Garrett Screen; 16 mesh stainless steel screen, size $275 \times 275 \mathrm{~mm}$, sampling depth 0 to $400 \mu \mathrm{m}$ ) and subsurface water (sampling depth $0.75 \mathrm{~m}$ ). For each sample, $250 \mathrm{ml}$ of water was filtered using a Sterivex-GS filter unit (pore size $0.2 \mu \mathrm{m}$; Millipore, Watford, UK) and DNA was extracted from the filter in a sucrose buffer using lysozyme, proteinase $\mathrm{K}$, sodium dodecyl sulphate and phenol-chloroform (Cunliffe et al., 2008). The re-suspended DNA was diluted in molecular grade water to a concen-

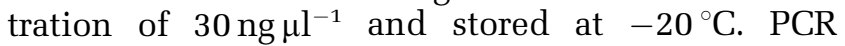
was performed using primers EUK $1209 \mathrm{~F}^{\mathrm{GC}}$ and 
UNI1392R (Diez et al., 2001). DGGE gels were prepared with $10 \%(\mathrm{v} / \mathrm{v})$ acrylamide/bisacrylamide with a $30-70 \%$ linear denaturant gradient and run in $1 \times$ Tris-acetate-EDTA buffer at $60^{\circ} \mathrm{C}$ for $1008 \mathrm{~V}$ hours (constant voltage $63 \mathrm{~V}, 16 \mathrm{~h}$ ) before being stained with SYBR Gold nucleic acid stain (Invitrogen, Paisley, UK). A composite DGGE profile was analysed using GelCompare II (Applied Maths, SintMartens-Latem, Belgium) by construction of a dendrogram. Selected DGGE bands were excised a

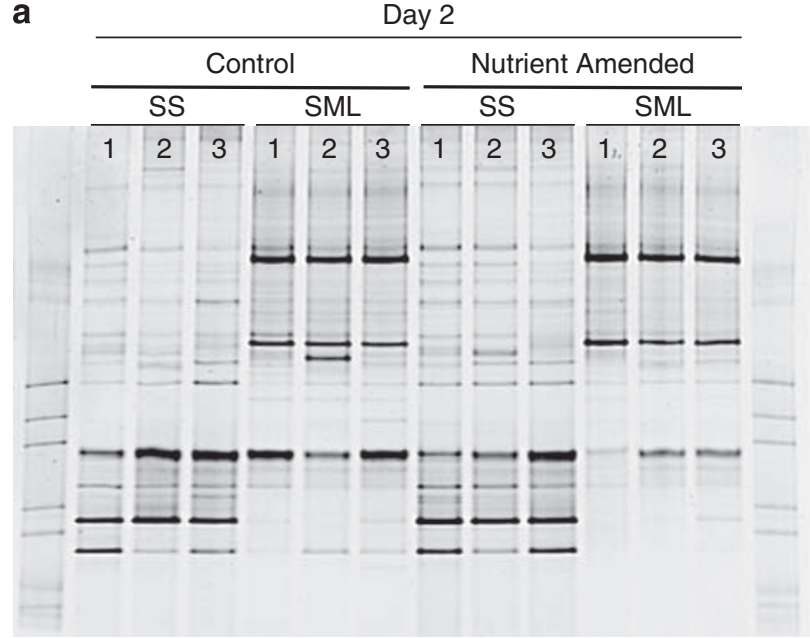

C

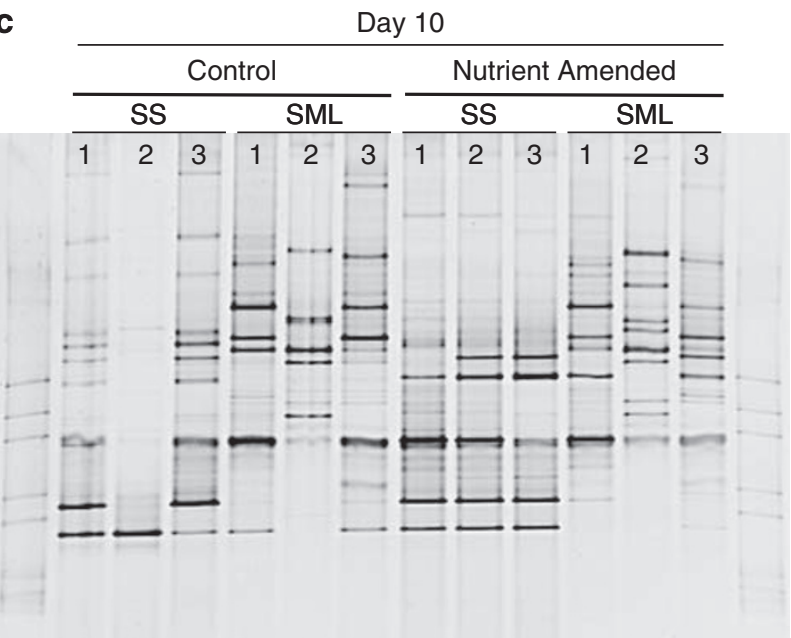

b

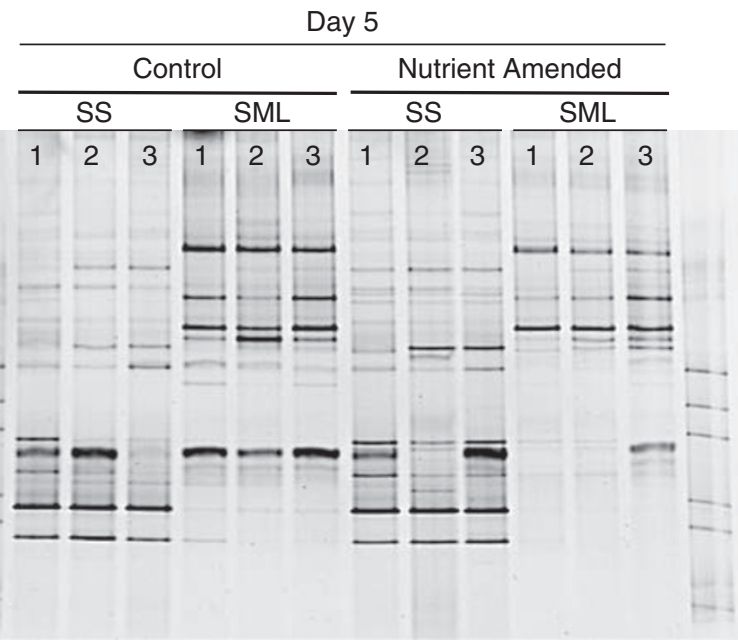

d

$$
\frac{\text { Day } 2}{\frac{\mathrm{C}}{\mathrm{SS} \mathrm{SML}} \frac{+\mathbf{N}}{\mathrm{SS} \mathrm{SML}}} \frac{\mathrm{C}}{\mathrm{SS} \mathrm{SML}} \frac{+\mathbf{N}}{\mathrm{SS} \mathrm{SML}} \frac{\mathrm{C}}{\mathrm{SS} \mathrm{SML}} \frac{+\mathbf{N}}{\mathrm{SS} \mathrm{SML}}
$$

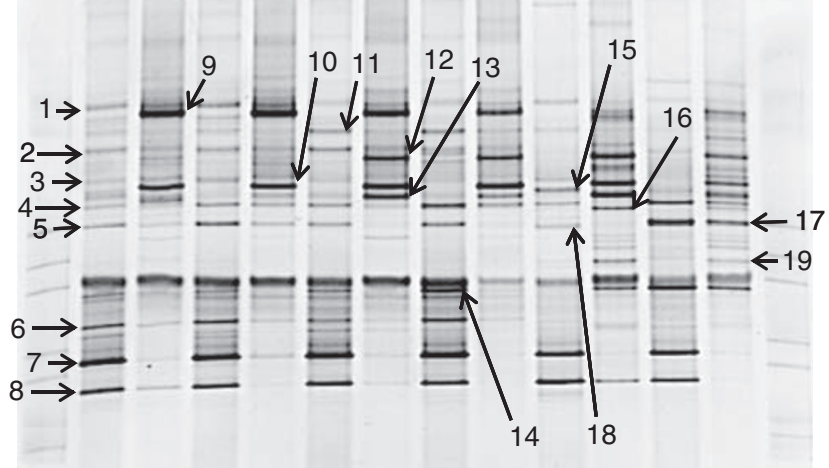

e Similarity (\%)

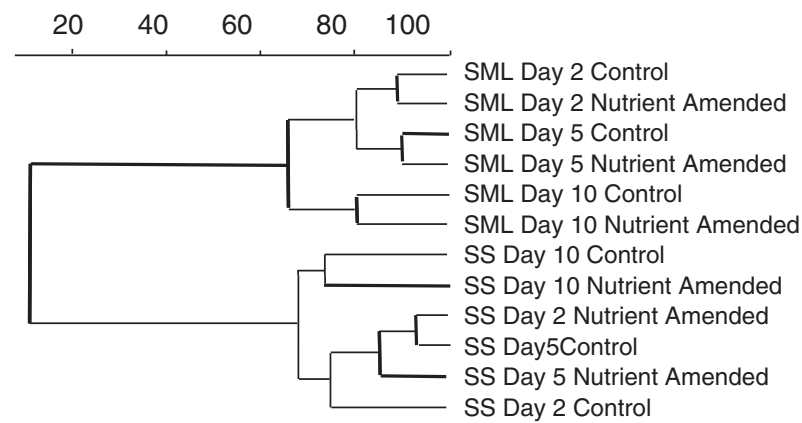

Figure 1 Denaturing gradient gel electrophoresis (DGGE) of Eukarya 18S rRNA gene amplicons. Samples were collected at the start (day 2; a), middle (day 5; b) and end (day 10; c) of a nutrient-amended phytoplankton bloom mesocosm experiment (Cunliffe et al, 2009c). Cognate samples were collected from both the subsurface water (SS; sampling depth $0.75 \mathrm{~m}$ ) and from the surface microlayer (SML; sampling depth 0 to $400 \mu \mathrm{m})(n=3$; three replicate control mesocosms and three replicate nutrient-amended mesocosms). A consolidated DGGE profile (d) was also made of all three sampling days by pooling equal amounts of the three replicate samples. The numbered arrows identify which DGGE bands were excised and sequenced in Table 1. An unweighted pair group method with arithmetic average (UPGMA) dendrogram was constructed from the consolidated DGGE to show the similarity of the lanes of the DGGE profile (e). 
and used as a target for a second round of PCR using the same primers. Sequences were obtained and are available in GenBank (accession numbers GQ428497 to GQ428515).

Denaturing gradient gel electrophoresis revealed that the diversity of Eukarya 18S rRNA genes in the surface microlayer samples was different compared with the diversity of Eukarya 18S rRNA genes in subsurface water samples (Figure 1). On days 2 and 5, the structures of the Eukarya 18S rRNA gene profiles in all three replicate mesocosms were very similar (Figures 1a and b); however, by day 10 there was some variation between replicate mesocosms (Figure 1c). Even with the relative increase in variation between replicates on day 10, all the surface microlayer Eukarya 18S rRNA gene profiles were similar (Figure 1d) and therefore formed a separate clade away from the subsurface samples in the dendrogram (Figure 1e). This indicates that there is a consistent surface microlayer-specific eukaryote community. As with the bacterioneuston and the bacterioplankton communities (Cunliffe et al., 2009c), there was no distinct effect of the nutrient amendment on the Eukarya 18S rRNA gene profiles in the mesocosms. One possible cause of the widespread effect, giving rise to a surface microlayer-specific eukaryote community, could be ultraviolet radiation.

Microscopic observations of surface microlayers have shown that a varied range of flagellate and ciliate protists can be present, with both motile and sessile forms (Joux et al., 2006, Sieburth, 1983). We detected using molecular methods (that is, none microscopically) a diverse range of eukaryote taxonomic groups in the samples (Table 1), including known flagellate and ciliate protist groups.

On days 2 and 5 on the surface microlayer samples, there was a high relative abundance of two DGGE bands (Figure 1; bands 9 and 10) that were associated with known Cercozoa 18S rRNA gene sequences (Table 1). The same bands were not visible in the subsurface water samples (Figure 1). This indicates that Cercozoa were a dominant protist group specifically in the mesocosm surface microlayers at this time. Cercozoa form a poorly understood eukaryote lineage and are ecologically and morphologically highly diverse (Keeling, 2001). Cercozoa 18S rRNA gene sequences are frequently observed in molecular studies of surface marine waters, but they are typically detected at low relative abundances, $<3 \%$ of clones in clone libraries, compared with other protist groups (Massana and Pedros-Alio, 2008, Marie et al., 2006). This study indicates that in the fjord surface microlayer, Cercozoa are numerically abundant and could be an important protist group affecting the bacterioneuston. Future work should aim to confirm whether Cercozoa are grazing on the bacterioneuston in the surface microlayer.

On day 10, the surface microlayer Eukarya $18 \mathrm{~S}$ rRNA gene profiles became more varied with DGGE bands associated with known ciliates (Ciliophora) becoming relatively more abundant (Figure 1 and Table 1). The surface microlayers of the fjord mesocosms were enriched with transparent exopolymer particles and other aggregates, giving the microlayer a gelatinous film structure (Cunliffe et al., 2009b). This contributes to the physical environment of the surface microlayer being different to subsurface water, particularly the enrichment of solid surfaces for cells to attach to (Cunliffe and Murrell, 2009). This could therefore create different protist niches than those in subsurface waters that would support the surface microlayer-specific protist communities observed (Figure 1).

We also detected non-protist metazoans (Figure 1d and Table 1), which could occupy higher trophic

Table 1 Sequence similarities of excised 18S rRNA gene DGGE bands in Figure 1

\begin{tabular}{|c|c|c|c|}
\hline Band & BLAST match & $\%$ Similarity (no. of bases) & Taxanomic group \\
\hline 1 & Skeletonema sp. NIES-324 (AB488611) & $98(191)$ & Stramenopiles; Bacillariophyta \\
\hline 2 & Uncultured marine clone (DQ647511) & $98(190)$ & Stramenopiles; ND \\
\hline 3 & Blastodinium pruvoti GA51 (FJ541189) & $94(192)$ & Alveolata; Dinophyceae \\
\hline 4 & Dictyocha speculum (U14385) & $98(188)$ & Stramenopiles; Dictyochophyceae \\
\hline 5 & Uncultured marine clone (EU371175) & $95(186)$ & Choanoflagellida; ND \\
\hline 6 & Mytilina ventralis (DQ297709) & 95 (184) & Metazoa; Rotifera \\
\hline 7 & Uncultured marine clone (EU371321) & $100(187)$ & ND \\
\hline 8 & Tortanus sp. (AY626995) & $93(190)$ & Metazoa; Arthropoda \\
\hline 9 & Cercozoa sp. CC-2009b (FJ824131) & $97(190)$ & Cercozoa \\
\hline 10 & Uncultured marine clone (AB275050) & $98(191)$ & Cercozoa \\
\hline 11 & Uncultured marine clone (AF290083) & $98(190)$ & Stramenopiles; ND \\
\hline 12 & Uncultured marine clone (EF526957) & $96(185)$ & Stramenopiles; ND \\
\hline 13 & Uncultured marine clone (DQ310332) & 95 (191) & Fungi; ND \\
\hline 14 & Metacylis sp. MNB99 (AY143567) & 94 (189) & Alveolata; Ciliophora \\
\hline 15 & Telonema subtilis (AJ564772) & $96(190)$ & Telonemida; Telonema \\
\hline 16 & Trichodina meretricis (FJ499387) & $97(191)$ & Alveolata; Ciliophora \\
\hline 17 & Codonella sp. HCB-2005 (DQ487193) & $93(188)$ & Alveolata; Ciliophora \\
\hline 18 & Chrysochromulina ericina (AM491030) & $93(192)$ & Haptophyceae; Prymnesiales \\
\hline 19 & Tintinnopsis uruguayensis (EU399542) & $98(187)$ & Alveolata; Ciliophora \\
\hline
\end{tabular}

Abbreviations: BLAST, basic local alignment search tool (Altschul et al., 1990); DGGE, denaturing gradient gel electrophoresis; ND, not determined. 
levels of the microbial loop (Azam et al., 1983). Metazoan predation in the surface microlayer is an important ecological process (Zaitsev, 2005). However, the mesh screen sampler may under-represent this size group when sampling (Agogue et al., 2004), and therefore metazoan distribution in the surface microlayer should not be considered in this study.

In summary, the structure of protist communities in the fjord surface microlayer is different to that in subsurface water. In particular, Cercozoa could be contributing to, by selective grazing, the specific bacterioneuston community structures that are present and hence warrant further study.

\section{Acknowledgements}

This work was supported by the Natural Environment Research Council (UK) through the project, SOLAS Bergen Mesocosm experiment (NE/E011446/1), which is part of the NERC-Surface Ocean Lower Atmosphere Study (SOLAS)-directed programme. We thank all the people involved in the project who helped with the preparation and sampling of the mesocosms.

\section{References}

Agogue H, Casamayor EO, Joux F, Obernosterer I, Dupuy C, Lantoine F et al. (2004). Comparison of samplers for the biological characterization of the sea surface microlayer. Limnol Oceanogr Methods 2: 213-225.

Altschul SF, Gish W, Miller W, Myers EW, Lipman DJ. (1990). Basic local alignment search tool. J Mol Biol 215: 403-410.

Azam F, Fenchel T, Field JG, Gray JS, Meyer-Reil LA, Thingstad F. (1983). The ecological role of watercolumn microbes in the sea. Mar Ecol Prog Ser 10: 257-263.

Cunliffe M, Harrison E, Salter M, Schafer H, UpstillGoddard RC, Murrell JC. (2009a). Comparison and validation of sampling strategies for the molecular microbial ecological analysis of surface microlayers. Aquat Microb Ecol 57: 69-77.

Cunliffe M, Murrell JC. (2009). The sea surface microlayer is a gelatinous biofilm. ISMEJ 3: 1001-1003.

Cunliffe M, Salter M, Mann PJ, Whiteley AS, UpstillGoddard RC, Murrell JC. (2009b). Dissolved organic carbon and bacterial populations in the gelatinous surface microlayer of a Norwegian fjord mesocosm. FEMS Microbiol Lett 299: 248-254.

Cunliffe M, Schafer H, Harrison E, Cleave S, UpstillGoddard RC, Murrell JC. (2008). Phylogenetic and functional gene analysis of the bacterial and archaeal communities associated with the surface microlayer of an estuary. ISMEJ 2: 776-789.

Cunliffe M, Whiteley AS, Schäfer H, Newbold L, Oliver A, Murrell JC. (2009c). Comparison of bacterioneuston and bacterioplankton dynamics during a phytoplankton bloom in a fjord mesocosm. Appl Environ Microbiol 75: 7173-7181.

Diez B, Pedros-Alio C, Marsh TL, Massana R. (2001). Application of denaturing gradient gel electrophoresis (DGGE) to study the diversity of marine picoeukaryotic assemblages and comparison of DGGE with other molecular techniques. Appl Environ Microbiol 67: 2942-2951.

Franklin MP, McDonald IR, Bourne DG, Owens NJ, Upstill-Goddard RC, Murrell JC. (2005). Bacterial diversity in the bacterioneuston (sea surface microlayer): the bacterioneuston through the looking glass. Environ Microbiol 7: 723-736.

Joux F, Agogue H, Obernosterer I, Dupuy C, Reinthaler T, Herndl GJ et al. (2006). Microbial community structure in the sea surface microlayer at two contrasting coastal sites in the northwestern Mediterranean Sea. Aquat Microb Ecol 42: 91-104.

Keeling PJ. (2001). Foraminifera and Cercozoa are related in actin phylogeny: two orphans find a home? Mol Biol Evol 18: 1551-1557.

Marie D, Zhu F, Balague V, Ras D Vaulot J. (2006). Eukaryotic picoplankton communities of the Mediterranean Sea in summer assessed by molecular approaches (DGGE, TTGE, QPCR). FEMS Microbiol Ecol 55: 403-415.

Massana R, Pedros-Alio C. (2008). Unveiling new microbial eukaryotes in the surface ocean. Curr Opin Microbiol 11: 213-218.

Pernthaler J. (2005). Predation on prokaryotes in the water column and its ecological implications. Nat Rev Microbiol 3: 537-546.

Sieburth JM. (1983). Microbiological and organic-chemical processes in the surface and mixed layers. In: Liss PS, Slinn WGN (eds). Air-Sea Exchange of Gases and Particles. Reidel Publishers Co: Hingham, MA, pp 121-172.

Zaitsev Y. (2005). Neuston of seas and oceans. In: Liss PS, Duce RA (eds). The Sea Surface and Global Change. Cambridge University Press: Cambridge, pp 371-382. 